\title{
A controlled study of eight months of physical training and reduction of blood pressure in children: the Odense schoolchild study
}

\author{
Henrik S Hansen, Karsten Froberg, Niels Hyldebrandt, Jens Rokkedal Nielsen
}

\begin{abstract}
Objective-To examine the effect of physical training on physical fitness and blood pressure in children aged $9-11$ years.

Design-Prospective randomised controlled intervention study of a sample of children drawn from a population survey of coronary risk factors in children.

Setting-Odense, Denmark.

Subjects -69 children with mean blood pressure $\geqslant 95$ th centile (hypertensive group) and 68 with mean blood pressure $<95$ th centile (normotensive group), randomly selected from a population of 1369 children.
\end{abstract}

Intervention-67 children were randomised to receive three extra lessons a week of an ordinary school physical education programme for eight months.

Main outcome measures-Physical fitness assessed by calculation of maximum oxygen uptake and blood pressure recorded by one unblinded observer.

Results-After three months neither blood pressure nor physical fitness had changed significantly. After adjustment for values in weight, height, heart rate, and the variable in question before training physical fitness rose significantly at the end of eight months' training, by $3.7 \mathrm{mlo}_{2} / \mathrm{kg} / \mathrm{min}(95 \%$ confidence interval $2 \cdot 2$ to 5.3 ) in the normotensive training subgroup and by $2 \cdot 1 \mathrm{mlo} / 2 \mathrm{~kg} / \mathrm{min}(0 \cdot 1$ to $4 \cdot 2)$ in the hypertensive training subgroup compared with that in the controls. Systolic and diastolic blood pressures in the training subgroups fell significantly by $6.5 \mathrm{~mm} \mathrm{Hg} \mathrm{(3.2} \mathrm{to} 9.9)$ and $4.1 \mathrm{~mm} \mathrm{Hg}(1.7$ to 6.6) respectively in the normotensive group and by $4.9 \mathrm{~mm} \mathrm{Hg} \mathrm{(0.7} \mathrm{to} 9.2)$ and $3.8 \mathrm{~mm} \mathrm{Hg} \mathrm{(0.9} \mathrm{to} \mathrm{6.6)}$ respectively in the hypertensive group.

Conclusions - Physical training lowers blood pressure and improves physical fitness in children and might have implications for an important non-pharmacological approach to primary prevention of essential hypertension.

\section{Introduction}

Regular exercise training generally is being recommended as a health measure for managing hypertension in adulthood. ${ }^{2} \mathrm{~A}$ coincident reduction in blood pressure after exercise training in hypertensive subjects and normotensive subjects ${ }^{+}$has been shown, but most reported studies suggest that the effect of training on blood pressure is non-existent or very small. ${ }^{5.7}$ Most of the longitudinal training studies reviewed, however, must be interpreted with caution because of inadequate design, principally the absence of adequate and randomised control groups receiving the same care during the training period..$^{8-10}$ No study exists in which the controlled effect of physical training on blood pressure and physical fitness has been examined in a population based sample of children.

The purpose of this investigation was to examine the effect of three extra lessons a week of an ordinary school physical education programme for eight months on blood pressure and physical fitness in children aged 9-11 years by use of a randomised controlled design.

Subjects and methods

SELECTION OF SUBJECTS

The children for this study were drawn from a total of 1369 children $(81.5 \%$ of the eligible population) aged 9-11 years who participated in the first phase of a prospective study (the Odense schoolchild study)."

We selected two groups of children: a hypertensive group $(n=69)$ consisting of all children with a mean blood pressure (diastolic blood pressure plus a third (systolic blood pressure minus diastolic blood pressure)) at ${ }^{\circ}$ or above the 95th centile for the entire population and a normotensive group $(n=68)$, comprising another $5 \%$, selected randomly from children with a mean blood pressure below the 95th centile. Five children in the hypertensive group did not want to participate and neither did 17 children originally selected for the normotensive group, but they were all replaced with children from the population by a randomised reselection procedure. The study group then included 64 children in the hypertensive group and 68 children in the normotensive group. After giving informed consent each child was randomised to either a training subgroup (hypertensive training subgroup $(\mathrm{n}=32)$; normotensive training subgroup $(n=35))$ or a control subgroup (hypertensive control subgroup $(\mathrm{n}=32)$; normotensive control subgroup $(\mathrm{n}=33))$.

The study was approved by the research ethics committee of the medical faculty of the University of Odense.

\section{STUDY DESIGN}

The study was a prospective controlled intervention study. All of the 132 participating children were examined immediately before training, at three months after the start of training, and at the end of eight months of training, according to the examination procedure reported previously. ${ }^{11}$ All blood pressures were measured with the children sitting after at least five minutes' rest. A random zero sphygmomanometer (Hawksley) was used to reduce observer bias, and all of the measurements were taken by the same person (HSH). One measurement was performed at each examination. Blood pressures were recorded to the nearest $2 \mathrm{~mm} \mathrm{Hg}$. Korotkoff phase IV was used as the estimate of diastolic blood pressure. ${ }^{7}$ Ratings of sexual maturity (range 1-5) were based on secondary sexual characteristics. ${ }^{12}$ Physical fitness as assessed by maximum oxygen uptake was determined indirectly with a maximum progressive exercise test on a bicycle ergometer and by calculating maximum oxygen uptake from maximum mechanical power. Previously we showed that the standard error calculated for maximum oxygen consumption estimated with this method was less than $3 \cdot 2 \% .^{13}$

\section{EXERCISE TRAINING}

The children in the training subgroup were divided into six different groups according to their place of 
residence within the municipality, and the groups followed the exercise training programme at these separate locations under the instruction of six different teachers. The programme consisted of extra lessons of an ordinary school physical education programme. Each training lesson was about 50 minutes long, including 10 minutes of warming up, and three lessons a week were scheduled for eight months. The content of the lessons did not differ from that of the regular schedule and included organised games, gymnastics, and exercises. The intensity of the lessons was evaluated alternately in six children by monitoring heart rate by telemetry (Sport tester PE-3000, Polar Electro, Finland) during a lesson. Both the training and the control subgroups continued their regular exercise schedule with two lessons weekly throughou the study period.

\section{STATISTICAL ANALYSIS}

Statistical analyses were performed on an intention to treat principle, so that children were treated statistically according to the experimental randomisation design throughout the study, even if their exercise training was discontinued. In each of the two groups the significance of the effects of state of training and sex were assessed from $F$ ratios with a $2 \times 2$ (training $\times$ sex level) analysis of variance with covariate adjustment for values before training of weight, height, heart rate, and either blood pressure or physical fitness, when appropriate. A repeated measures design was used for estimating trends with time. ${ }^{14} 15$ The assumption of homogeneity of variances, which indicates that the variance-covariance matrices of the groups are equivalent, was assessed using Box's $M$ statistic $^{16}$ and Bartlett's test. ${ }^{17}$ All statistical analyses were carried out with the statistical package for the social sciences (SPSS) software. A probability value of less than 0.05 was considered significant. All statistical tests were two tailed.

TABLE I-Physical characteristics of children before and after training. Values are means (SDs)

\begin{tabular}{|c|c|c|c|c|}
\hline & \multicolumn{2}{|c|}{ Before intervention } & \multicolumn{2}{|c|}{ After intervention } \\
\hline & $\begin{array}{c}\text { Training } \\
\text { subgroup } \\
(n=67)\end{array}$ & $\begin{array}{c}\text { Control } \\
\text { subgroup } \\
(n=65)\end{array}$ & $\begin{array}{c}\text { Training } \\
\text { subgroup } \\
(\mathrm{n}=67)\end{array}$ & $\begin{array}{l}\text { Control } \\
\text { subgroup } \\
(n=65)\end{array}$ \\
\hline Weight $(\mathrm{kg})$ & $37 \cdot 4(8 \cdot 6)$ & $39 \cdot 3(7 \cdot 3)$ & $40 \cdot 6(9 \cdot 1)$ & $42 \cdot 1(7 \cdot 7)$ \\
\hline Height $(\mathrm{cm})$ & $144 \cdot 9(7 \cdot 4)$ & $146 \cdot 7(5 \cdot 6)$ & $148 \cdot 3(8 \cdot 0)$ & $150 \cdot 2(5 \cdot 8)$ \\
\hline Triceps skinfold thickness $(\mathrm{cm})$ & $1.3(0.5)$ & $1 \cdot 3(0 \cdot 5$ & $1.3(0.6)$ & $1 \cdot 2(0 \cdot 6)$ \\
\hline Quetelet's index (weight/height ') & $17 \cdot 7(2 \cdot 8)$ & $18 \cdot 2(2 \cdot 8)$ & $18 \cdot 3(2 \cdot 9)$ & $18 \cdot 6(2 \cdot 7)$ \\
\hline Heart rate $($ beats/min $)$ & $91 \cdot 8^{\star}(11 \cdot 4)$ & $96 \cdot 0(12 \cdot 0)$ & $85 \cdot 9(11 \cdot 5)$ & $88 \cdot 0(12 \cdot 5)$ \\
\hline
\end{tabular}

${ }^{\star} \mathrm{p}<0.05$ compared with control group.

TABLE II-Mean $(S D)$ values of physical fitness $\left(\mathrm{ml} \mathrm{O}_{2} / \mathrm{kg} / \mathrm{min}\right)$ before exercise training, after three months, and after eight months

\begin{tabular}{|c|c|c|c|c|c|c|c|c|c|c|c|c|}
\hline & \multicolumn{2}{|c|}{ Normotensive boys } & \multicolumn{2}{|c|}{ Normotensive girls } & \multicolumn{2}{|c|}{$F$ ratios $^{\star}$} & \multicolumn{2}{|c|}{ Hypertensive boys } & \multicolumn{2}{|c|}{ Hypertensive girls } & \multicolumn{2}{|c|}{$F$ ratios ${ }^{\star}$} \\
\hline & $\begin{array}{c}\text { Training } \\
\text { subgroup } \\
(\mathrm{n}=18)\end{array}$ & $\begin{array}{c}\text { Control } \\
\text { subgroup } \\
(\mathbf{n}=17)\end{array}$ & $\begin{array}{c}\text { Training } \\
\text { subgroup } \\
(\mathrm{n}=17)\end{array}$ & $\begin{array}{c}\text { Control } \\
\text { subgroup } \\
(\mathrm{n}=16)\end{array}$ & $\begin{array}{l}\text { Intervention; } \\
\quad \operatorname{sex}\end{array}$ & $\begin{array}{c}\text { Intervention- } \\
\text { sex } \\
\text { interaction }\end{array}$ & $\begin{array}{c}\text { Training } \\
\text { subgroup } \\
(\mathbf{n}=17)\end{array}$ & $\begin{array}{c}\text { Control } \\
\text { subgroup } \\
(\mathrm{n}=16)\end{array}$ & $\begin{array}{c}\text { Training } \\
\text { subgroup } \\
(\mathrm{n}=15)\end{array}$ & $\begin{array}{l}\text { Control } \\
\text { subgroup } \\
(\mathrm{n}=16)\end{array}$ & $\begin{array}{l}\text { Intervention; } \\
\text { sex }\end{array}$ & $\begin{array}{l}\text { Intervention- } \\
\text { sex } \\
\text { interaction }\end{array}$ \\
\hline Before training & $51 \cdot 0(5 \cdot 8)$ & $53 \cdot 1(4 \cdot 2)$ & $48 \cdot 9(4 \cdot 4)$ & $46 \cdot 9(6 \cdot 4)$ & $1 \cdot 1 ; 17 \cdot 1 \dagger$ & $2 \cdot 6$ & $52 \cdot 3(7 \cdot 5)$ & $48 \cdot 1(7 \cdot 6)$ & $45 \cdot 6(5 \cdot 0)$ & $41 \cdot 8(6 \cdot 9)$ & $7 \cdot 7 \dagger ; 35 \cdot 3 \dagger$ & $0 \cdot 4$ \\
\hline Three months & $50.7(6.4)$ & $50 \cdot 2(5 \cdot 7)$ & $48 \cdot 4(4 \cdot 2)$ & $46 \cdot 8(6 \cdot 8)$ & $2 \cdot 2 ; 1 \cdot 0$ & $3 \cdot 0$ & $51.5(6.9)$ & $48 \cdot 4(9 \cdot 3)$ & $44 \cdot 9(5 \cdot 3)$ & $41 \cdot 4(6 \cdot 9)$ & $1 \cdot 3 ; 0.0$ & $0 \cdot 2$ \\
\hline Eight months & $55 \cdot 3(6 \cdot 3)$ & $52 \cdot 5(4 \cdot 3)$ & $51 \cdot 3(5 \cdot 0)$ & $46 \cdot 6(6 \cdot 4)$ & $23 \cdot 3+; 3 \cdot 8$ & 0.9 & $54.4(7.9)$ & $48 \cdot 6(9 \cdot 7)$ & $47 \cdot 2(5 \cdot 7)$ & $41 \cdot 2(7 \cdot 1)$ & $5 \cdot 1+; 1 \cdot 8$ & $0 \cdot 1$ \\
\hline$F$ ratio (time) & $25 \cdot 6 \dagger$ & $10 \cdot 0 \dagger$ & $8 \cdot 7 \dagger$ & $0 \cdot 1$ & & & $9 \cdot 3 t$ & $0 \cdot 2$ & $5 \cdot 0 \dagger$ & $0 \cdot 3$ & & \\
\hline
\end{tabular}

^Adjusted for values before training in weight, height, and heart rate. Values at three and eight months, respectively, are also adjusted for value in physical fitness before training. tp<0.05.

TABLE III - Mean $(S D)$ systolic blood pressure $(\mathrm{mm} \mathrm{Hg})$ before exercise training, after three months, and after eight months

\begin{tabular}{|c|c|c|c|c|c|c|c|c|c|c|c|c|}
\hline & \multicolumn{2}{|c|}{ Normotensive boys } & \multicolumn{2}{|c|}{ Normotensive girls } & \multicolumn{2}{|c|}{$F$ ratios $^{\star}$} & \multicolumn{2}{|c|}{ Hypertensive boys } & \multicolumn{2}{|c|}{ Hypertensive girls } & \multicolumn{2}{|c|}{$F$ ratios ${ }^{\star}$} \\
\hline & $\begin{array}{c}\text { Training } \\
\text { subgroup } \\
(\mathrm{n}=18)\end{array}$ & $\begin{array}{l}\text { Control } \\
\text { subgroup } \\
(\mathrm{n}=17)\end{array}$ & $\begin{array}{c}\text { Training } \\
\text { subgroup } \\
(\mathbf{n}=17)\end{array}$ & $\begin{array}{c}\text { Control } \\
\text { subgroup } \\
(\mathrm{n}=16)\end{array}$ & $\begin{array}{l}\text { Intervention; } \\
\text { sex }\end{array}$ & $\begin{array}{l}\text { Intervention- } \\
\text { sex } \\
\text { interaction }\end{array}$ & $\begin{array}{c}\text { Training } \\
\text { subgroup } \\
(\mathrm{n}=17)\end{array}$ & $\begin{array}{l}\text { Control } \\
\text { subgroup } \\
(\mathrm{n}=16)\end{array}$ & $\begin{array}{c}\text { Training } \\
\text { subgroup } \\
(\mathrm{n}=15)\end{array}$ & $\begin{array}{c}\text { Control } \\
\text { subgroup } \\
(\mathrm{n}=16)\end{array}$ & $\begin{array}{l}\text { Intervention; } \\
\text { sex }\end{array}$ & $\begin{array}{c}\text { Intervention- } \\
\text { sex } \\
\text { interaction }\end{array}$ \\
\hline Before training & $101 \cdot 3(13 \cdot 0)$ & $108 \cdot 0(9 \cdot 0)$ & $101 \cdot 5(5 \cdot 8)$ & $105 \cdot 8(7 \cdot 3)$ & $4 \cdot 1+; 0 \cdot 3$ & $0 \cdot 3$ & $113 \cdot 4(11 \cdot 1)$ & $114 \cdot 3(10 \cdot 3)$ & $115 \cdot 9(11 \cdot 2)$ & $114 \cdot 4(9 \cdot 4)$ & $2 \cdot 2 ; 0 \cdot 1$ & $0 \cdot 0$ \\
\hline Three months & $105 \cdot 0(11 \cdot 0)$ & $107 \cdot 1(9 \cdot 7)$ & $102 \cdot 7(9 \cdot 1)$ & $103 \cdot 5(6 \cdot 6)$ & $1 \cdot 0 ; 1.5$ & $0 \cdot 0$ & $113 \cdot 1(9 \cdot 3)$ & $115 \cdot 5(9 \cdot 2)$ & $113 \cdot 2(10 \cdot 6)$ & $116 \cdot 3(9 \cdot 0)$ & $1 \cdot 4 ; 0 \cdot 0$ & $0 \cdot 7$ \\
\hline Eight months & $96 \cdot 9(8 \cdot 6)$ & $108 \cdot 8(9 \cdot 4)$ & $98 \cdot 2(8 \cdot 3)$ & $105 \cdot 1(5 \cdot 4)$ & $15 \cdot 0 \dagger ; 0 \cdot 1$ & $1 \cdot 3$ & $107 \cdot 2(7 \cdot 0)$ & $116 \cdot 3(10 \cdot 3)$ & $115 \cdot 2(9 \cdot 6)$ & $114 \cdot 0(9 \cdot 5)$ & $5 \cdot 8+; 1.9$ & $4 \cdot 8 \dagger$ \\
\hline$F$ ratio (time) & 9.0† & $0 \cdot 4$ & $2 \cdot 8$ & 0.5 & & & $6 \cdot 2 t$ & 0.4 & 0.7 & 0.6 & & \\
\hline
\end{tabular}

^Adjusted for values before training in weight, height, and heart rate. Values at three and eight months, respectively, are also adjusted for value in systolic blood pressure before training. tp $<0.05$. 

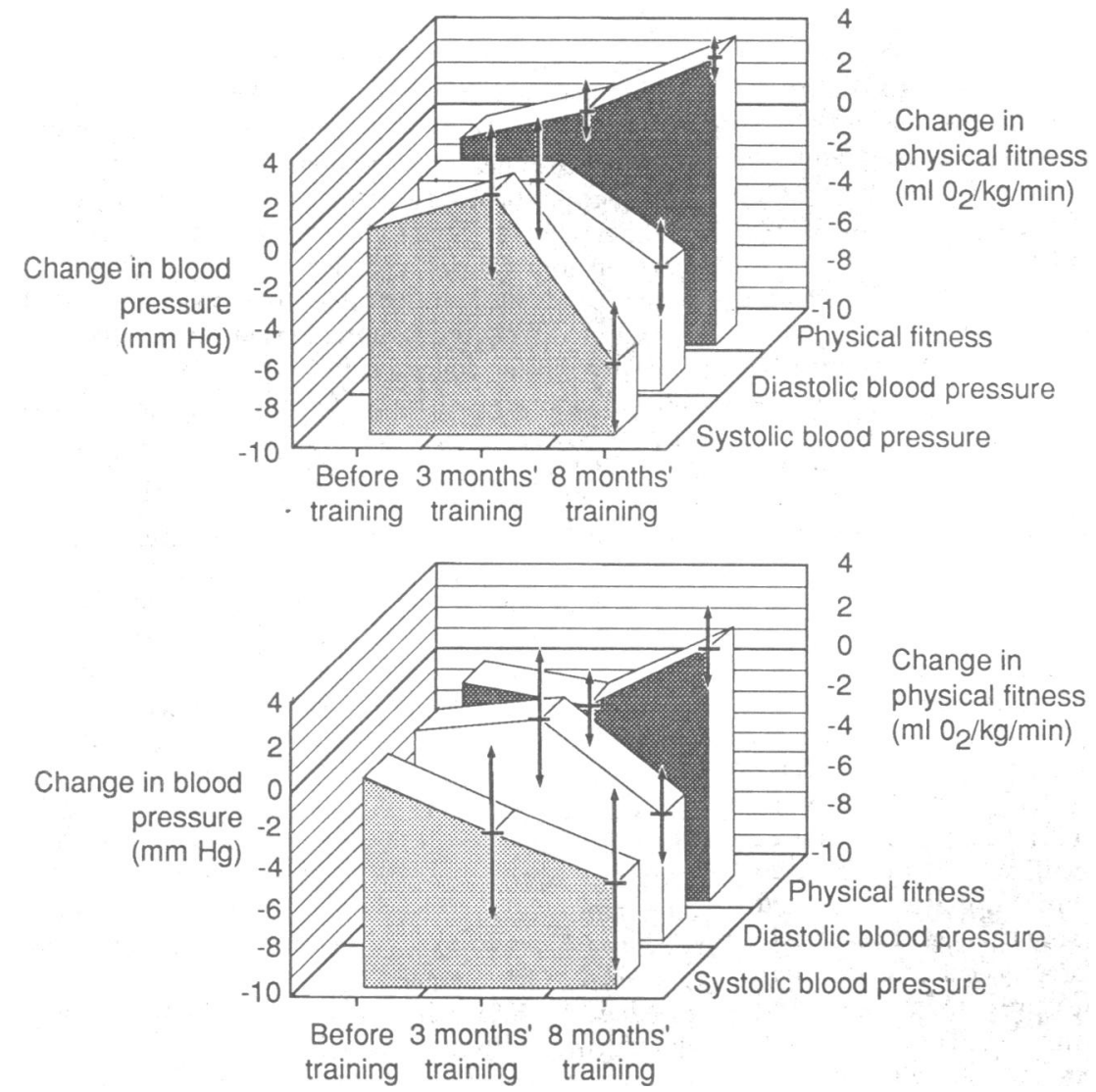

Changes in blood pressure and physical fitness in 67 children after three and eight months of training compared with respective changes in 65 children randomised to no training. (a) Normotensive children, $(b)$ hypertensive children. V'alues adjusted for values before training in weight, height, heart rate, and variable in question. Arrows indicate $95 \%$ confidence intervals; no significant change observed when arrow crosses zero

and in the hypertensive group was $2 \cdot 1 \mathrm{mlo}_{2} / \mathrm{kg} / \mathrm{min}$ $(0 \cdot 1$ to $4 \cdot 2)$.

\section{BLOOD PRESSURE}

Before training the normotensive training subgroup had a significantly lower systolic blood pressure than that of the normotensive control subgroup $(F$ ratio $4 \cdot 1)$ (table III), but all differences in values before training were controlled for by the analysis of variance model in the subsequent analyses. At three months systolic blood pressure did not differ significantly. Systolic blood pressure differed significantly between the training subgroup and the control subgroup after the training period in both the normotensive group $(F$ ratio $15 \cdot 0)$ and the hypertensive group $(F$ ratio $5 \cdot 8)$. The mean fall in systolic blood pressure (figure) was $6.5 \mathrm{~mm} \mathrm{Hg}(3.2$ to 9.9$)$ in the normotensive training subgroup and $4.9 \mathrm{~mm} \mathrm{Hg}(0.7$ to 9.2$)$ in the hypertensive training subgroup. No difference between the sexes was observed at the end of the training period (table III). Sex, however, had a significant effect in the hypertensive group, as shown by the significant interaction effect of intervention and sex. At the end of eight months of training systolic blood pressure had fallen significantly in boys in both training subgroups.
Diastolic blood pressure at three months of training was not significantly different (table IV). At the end of the eight month training period it was significantly lower in both training subgroups than in the control subgroups (mean fall $4.1 \mathrm{~mm} \mathrm{Hg}(1.7$ to $6.6 \mathrm{~mm} \mathrm{Hg}$ ) in the normotensive training subgroup and $3.8 \mathrm{~mm} \mathrm{Hg}$ $(0.9$ to $6.6 \mathrm{~mm} \mathrm{Hg})$ in the hypertensive training subgroup; figure).

\section{Discussion}

No other published study has examined the controlled effect of physical training on blood pressure and physical fitness in a population based group of children. Our results therefore provide the first objective support for the effectiveness of physical training in increasing physical fitness and lowering blood pressure among populations of children.

Careful precautions were taken to ensure a highly accurate and precise estimate of the intra-arterial blood pressure, but some methodological problems might be inherent in the blood pressure recordings in that the observer was not blinded. All recordings, however, were made by the same experienced observer, all were measured to the nearest $2 \mathrm{~mm} \mathrm{Hg}$, and all were measured blindly with a random zero sphygmomanometer. Therefore if a bias was present we do not believe that it significantly interfered with the main outcome and the main conclusions of the study.

More than three quarters of the children who were randomised to the training programme complied with it throughout. The significance of any intervention study, however, carries the risk of bias due to nonresponders. This bias was ruled out by including children in the analyses who did not comply with the programme throughout, and these events may have contributed to an underestimation of the potential effect of the programme.

The apparent lack of effect on blood pressure and physical fitness of three months' physical training is remarkable and in agreement with the results of others. ${ }^{18-20}$ The findings imply that the adaptive responses to physical training occur rather slowly over a prolonged period.

The study of the effectiveness of non-pharmacological health measures for primary prevention of coronary heart disease among populations of children is relatively new. ${ }^{21}$ Attempts at educational intervention programmes that include recommendations on diet and physical activity alone ${ }^{22-24}$ have not successfully controlled hypertension. A general approach combining dietary management and low levels of drug treatment significantly reduced blood pressure in hypertensive children after 30 months of observation. ${ }^{25}$ Importantly, our study showed that the effect of blood pressure and physical fitness could be obtained across large numbers of children within the framework of ordinary school facilities and staff. There is, however, a real question of whether the beneficial effects of physical training can be maintained or enhanced in the long term, but recommendations should be offered for increasing participation in exercise and for improving

TABLE IV-Mean $(S D)$ diastolic blood pressure $(\mathrm{mm} \mathrm{Hg})$ before exercise training, after three months, and after eight months

\begin{tabular}{|c|c|c|c|c|c|c|c|c|c|c|c|c|}
\hline & \multicolumn{2}{|c|}{ Normotensive boys } & \multicolumn{2}{|c|}{ Normotensive girls } & \multicolumn{2}{|c|}{$F$ ratios $^{\star}$} & \multicolumn{2}{|c|}{ Hypertensive boys } & \multicolumn{2}{|c|}{ Hypertensive girls } & \multicolumn{2}{|c|}{$F$ ratios ${ }^{\star}$} \\
\hline & $\begin{array}{c}\text { Training } \\
\text { subgroup } \\
(\mathbf{n}=18)\end{array}$ & $\begin{array}{l}\text { Control } \\
\text { subgroup } \\
(\mathrm{n}=17)\end{array}$ & $\begin{array}{c}\text { Training } \\
\text { subgroup } \\
(\mathbf{n}=17)\end{array}$ & $\begin{array}{c}\text { Control } \\
\text { subgroup } \\
(\mathrm{n}=16)\end{array}$ & $\begin{array}{l}\text { Intervention; } \\
\text { sex }\end{array}$ & $\begin{array}{c}\text { Intervention- } \\
\text { sex } \\
\text { interaction }\end{array}$ & $\begin{array}{c}\text { Training } \\
\text { subgroup } \\
(\mathrm{n}=17)\end{array}$ & $\begin{array}{l}\text { Control } \\
\text { subgroup } \\
(\mathbf{n}=16)\end{array}$ & $\begin{array}{c}\text { Training } \\
\text { subgroup } \\
(\mathrm{n}=15)\end{array}$ & $\begin{array}{c}\text { Control } \\
\text { subgroup } \\
(\mathrm{n}=16)\end{array}$ & $\begin{array}{l}\text { Intervention; } \\
\text { sex }\end{array}$ & $\begin{array}{c}\text { Intervention- } \\
\text { sex } \\
\text { interaction }\end{array}$ \\
\hline Before training & $67 \cdot 8(8 \cdot 1)$ & $72 \cdot 7(6 \cdot 7)$ & $66 \cdot 0(5 \cdot 2)$ & $68 \cdot 0(7 \cdot 7)$ & $2.8 ; 3.9$ & $0 \cdot 8$ & $76 \cdot 8(7 \cdot 4)$ & $76 \cdot 5(7 \cdot 2)$ & $75 \cdot 6(10 \cdot 0)$ & $76 \cdot 3(10 \cdot 2)$ & $0.5 ; 0.4$ & $0 \cdot 1$ \\
\hline Three months & $70 \cdot 7(7 \cdot 7)$ & $72 \cdot 5(5 \cdot 8)$ & $67 \cdot 9(6 \cdot 3)$ & $69 \cdot 1(6 \cdot 8)$ & $0 \cdot 0 ; 2 \cdot 0$ & $0 \cdot 0$ & $76 \cdot 1(7 \cdot 7)$ & $75 \cdot 5(8 \cdot 2)$ & $75.5(8.9)$ & $77 \cdot 0(5 \cdot 2)$ & $0 \cdot 2 ; 0 \cdot 1$ & $1 \cdot 0$ \\
\hline Eight months & $68 \cdot 3(7 \cdot 1)$ & $73 \cdot 4(5 \cdot 0)$ & $65 \cdot 3(6 \cdot 0)$ & $72 \cdot 3(5 \cdot 3)$ & $11 \cdot 3+; 0 \cdot 4$ & 1.9 & $74 \cdot 0(6 \cdot 7)$ & $78 \cdot 9(6 \cdot 1)$ & $76 \cdot 5(5 \cdot 6)$ & $79 \cdot 0(7 \cdot 0)$ & $7 \cdot 0 \dagger ; 1 \cdot 7$ & 0.5 \\
\hline$F$ ratio (time) & 1.4 & $0 \cdot 2$ & $1 \cdot 3$ & $3.7 \dagger$ & & & 1.8 & $2 \cdot 3$ & $0 \cdot 3$ & 1.5 & & \\
\hline
\end{tabular}

${ }^{\star}$ Adjusted for values before training in weight, height, and heart rate. Values at three and eight months, respectively, are also adjusted for value in diastolic blood pressure before training. $t p<0.05$. 
children's attitudes toward physical activity within the school environment. ${ }^{26}$

Supported by the Danish Health Insurance Foundation, the Danish Health Services Development Foundation, the Danish Heart Foundation, the Health Insurance Foundation of Denmark, the Danish Medical Research Council, the Funen Prevention Council, the Danish Sports Research Council, and the Rosalie Petersen Foundation.

1 WHO Scientific Group. Primary prevention of essential hypertension. WHO Tech Rep Ser 1983;686:1-40.

2 The 1988 report of the Joint National Committee on Detection, Evaluation, and Treatment of High Blood Pressure. Arch Intern Med 1988;148:1023-38.

Nelson L, Jennings GL, Esler MD, Korner PI. Effect of changing levels of physical activity on blood pressure and haemodynamics in essential physical activity on blood pressure

4 Jennings G, Nelson L, Nestel P, Esler M, Korner P, Burton D, et al. The effects of changes in physical activity on major cardiovascular risk factors, hemodynamics, sympathetic function, and glucose utilization in man: a controlled study of four levels of activity. Circulation 1986;73:30-40.

5 Seals DR, Hagberg JM. The effect of exercise training on human hypertension a review. Med Sci Sports Exerc 1984;16:207-15.

6 Subcommittee on Nonpharmacological Therapy. Nonpharmacological Subcommittee on Nonpharmacological Therapy. Nonpharmacological
approaches to the control of high blood pressure. Hypertension 1986;8: 414-67.

7 Report of the Second Task Force on Blood Pressure Control in Children1987. Pediatrics $1987 ; 79: 1-25$

8 Fagard R. Habitual physical activity, training, and blood pressure in normoand hypertension. Int F Sports Med 1985;6:57-67.

9 Montoye HJ. Physical activity, physical fitness, and heart disease risk factors in children. In: Stull GA, Eckert HM, eds. Effects of physical activity on children. Champaign, Illinois: Human Kinetics Publishers, 1986:127-52. American Academy of Physical Education Papers, No 19.

10 Vaccaro P, Mahon AD. The effects of exercise on coronary heart disease risk factors in children. Sports Med 1989;8:139-53.

11 Hansen HS, Hyldebrandt N, Nielsen JR, Froberg K. Blood pressure distribution in a school-age population aged 8-10 years-the Odense schoolchild study. f Hypertens 1990;8:641-6.
12 Tanner JM, ed. Growth at adolescence. Oxford: Blackwell Scientific Publicaions, 1962

13 Hansen HS, Froberg K, Nielsen JR, Hyldebrandt N. A new approach to assessing maximal aerobic power in children: the Odense school child study. Eur F Appl Physiol 1989;58:618-24.

14 Cole IWL, Grizzle IE. Applications of multivariate analysis of variance to repeated measures experiments. Biometrics 1966;22:810-28.

15 O'Brien RG, Kaiser MK. MANOVA method for analyzing repeated measure designs: an extensive primer. Psychol Bull 1985;97:316-33.

16 SPSS Inc. SPSSX user's guide. New York: McGraw-Hill Book Company, 1983:487-8.

17 Gunsolley JC, Chinchilli VM, Koertge TE, Palcanis KG, Sarbin AG, Brooks $\mathrm{CN}$. The use of repeated measures analysis of variance for plaque and gingival indices. F Clin Periodontol 1989;16:156-63.

18 Eriksson BO, Koch G. Effect of physical training on haemodynamic response during submaximal and maximal exercise in 11-13-year old bovs. Acta Physiol Scand 1973;87:27-39.

19 Dwyer T, Coonan WE, Leitch DR, Hetzel BS, Baghurst RA. An investigation of the effects of daily physical activity on the health of primary school

20 Linder CW, DuRant RH, Mahoney OM. The effect of physical conditioning on serum lipids and lipoproteins in white male adolescents. Med Sci Sports on serum lipids and
Exerc 1983;15:232-6.

21 Stone EJ. School-based health research funded by the National Heart, Lung, and Blood Institute. F Sch Health 1985;55:168-74.

22 Puska P, Vartiainen E, Pallonen U, Salonen JT, Pö̀hiä P, Koskela K, et al. The North Karelia Youth Project: evaluation of two years of intervention on health behavior and CVD risk factors among 13 to 15 -year-old children. Prev Med 1982;11:550-70

23 Tell GS, Vellar OD. Non-communicable disease risk factor intervention in Norwegian adolescents: the Oslo youth study. In: Hetzel BS, Berenson GS eds. Cardiovascular risk factors in childhood: epidemiology and prevention. Amsterdam: Elsevier, 1987:203-17.

24 Walter HJ, Hofman A, Vaughan AD, Wynder EL. Modification of risk factor for coronary heart disease. $N$ Engl f Med 1988;318:1093-1100.

25 Berenson GS, Shear CL, Chiang YK, Webber LS, Voors AW. Combined lowdose medication and primary intervention over a 30-month period for sustained high blood pressure in childhood. Am f Med Sci 1990;299:79-86. 26 Demarco T, Sidney K. Enhancing children's participation in physical activity. I Sch Health 1989;59:337-40.

(Accepted 4 fuly 1991)
Division of Clinical

Neurosciences, Lilly Research Laboratories, Eli

Lilly and Company,

Indianapolis, Indiana

46285, USA

Charles M Beasley Jr, MD,

clinical resource physician

Bruce E Dornseif, PHD,

research scientist

Janet C Bosomworth, BS, statistician

Mary E Sayler, MS,

statistician

Alvin H Rampey Jr, PHD, senior statistician

John H Heiligenstein, MD, clinical research physician

Vicki L Thompson, MSN, clinical research administrator David J Murphy, BBA, senior information analyst

Daniel N Masica, MD,

international research adviser

Correspondence to: Dr Charles M Beasley Jr, Lilly Research Laboratories, Eli Lilly and Company, Lilly Corporate Center 2128,

Indianapolis, Indiana 46285 , USA.

BM7 1991;303:685-92

\section{Fluoxetine and suicide: a meta-analysis of controlled trials of treatment for depression}

Charles M Beasley Jr, Bruce E Dornseif, Janet C Bosomworth, Mary E Sayler, Alvin H Rampey Jr, John H Heiligenstein, Vicki L Thompson, David J Murphy, Daniel N Masica

\section{Abstract}

Objective-A comprehensive meta-analysis of clinical trial data was performed to assess the possible association of fluoxetine and suicidality (suicidal acts and ideation).

Design-Retrospective analysis of pooled data from 17 double blind clinical trials in patients with major depressive disorder comparing fluoxetine $(\mathbf{n}=$ $1765)$ with a tricyclic antidepressant $(n=731)$ or placebo $(n=569)$, or both.

Main outcome measures-Multiple data sources were searched to identify patients with suicidal acts. Suicidal ideation was assessed with item 3 of the Hamilton depression rating scale, which systematically rates suicidality. Emergence of substantial suicidal ideation was defined as a change in the rating of this item from 0 or 1 at baseline to 3 or 4 during double blind treatment; worsening was defined as any increase from baseline; improvemen was defined as a decrease from baseline at the last visit during the treatment.

Results - Suicidal acts did not differ significantly in comparisons of fluoxetine with placebo $(0 \cdot 2 \% v$ $0 \cdot 2 \%, p=0 \cdot 494$, Mantel-Haenszel adjusted incidence difference) and with tricyclic antidepressants $(0.7 \%$ $v 0.4 \%, \mathrm{p}=0.419)$. The pooled incidence of suicidal acts was $0.3 \%$ for fluoxetine, $0.2 \%$ for placebo, and $0.4 \%$ for tricyclic antidepressants, and fluoxetine did not differ significantly from either placebo $(p=0.533$, Pearson's $\left.\chi^{2}\right)$ or tricyclic antidepressants $(\mathbf{p}=0.789)$. Suicidal ideation emerged marginally significantly less often with fluoxetine than with placebo $(0.9 \% v$ $2 \cdot 6 \%, p=0.094)$ and numerically less often than with tricyclic antidepressants $(1.7 \% \vee 3.6 \%, p=0 \cdot 102)$.
The pooled incidence of emergence of substantial suicidal ideation was $1 \cdot 2 \%$ for fluoxetine, $2 \cdot 6 \%$ for placebo, and $3.6 \%$ for tricyclic antidepressants. The incidence was significantly lower with fluoxetine than with placebo $(p=0.042)$ and tricyclic antidepressants $(p=0.001)$. Any degree of worsening of suicidal ideation was similar with fluoxetine and placebo $(15.4 \% v 17.9 \%, p=0 \cdot 196)$ and with fluoxetine and tricyclic antidepressants $(15.6 \%$ v $16.3 \%$, $\mathbf{p}=\mathbf{0 . 7 9 3 )}$. The pooled incidence of worsening of suicidal ideation was $15 \cdot 3 \%$ for fluoxetine, $17.9 \%$ for placebo, and $16.3 \%$ for tricyclic antidepressants. The incidence did not differ significantly with fluoxetine and placebo $(p=0 \cdot 141)$ or tricyclic antidepressants $(p=0.542)$. Suicidal ideation improved significantly more with fluoxetine than with placebo $(72.0 \% v 54.8 \%, p<0.001)$ and was similar to the improvement with tricyclic antidepressants $(72.5 \% \mathrm{v}$ $69.8 \%, p=0.294)$. The pooled incidence of improvement of suicidal ideation was $\mathbf{7 2 \cdot 2} \%$ for fluoxetine, $\mathbf{5 4 . 8 \%}$ for placebo, and $\mathbf{6 9 . 8 \%}$ for tricyclic antidepressants. The incidence with fluoxetine was significantly greater than with placebo $(p<0.001)$ and did not differ from that with tricyclic antidepressants $(\mathbf{p}=\mathbf{0} \cdot 296)$.

Conclusion-Data from these trials do not show that fluoxetine is associated with an increased risk of suicidal acts or emergence of substantial suicidal thoughts among depressed patients.

\section{Introduction}

Because depression is an important risk factor for suicide $^{1-3}$ there is a need to study the effects of 